\title{
The Impact of Ethnic Background and Demographics on Conflict Management Styles' Preferences: A Study of Six Sub-Cultures of Pakistan
}

\begin{abstract}
Muhammad Khan Riaz ${ }^{1}$, Waseef Jamal' ${ }^{2}$, Farzand Ali Jan ${ }^{3}$
Abstract

This study aims to investigate conflict management style preferences of employees and how ethnic background along with other demographics affects these preferences. Using online survey, 296 responses are analyzed from the Govt., education sector, NGOs and private sector employees. Respondents comprise of Pakhtuns of Khyber Pakhtunkhwa and FATA, Punjabis, Hindkowan, Urdu speaking community and Chitralis. Results show that there are significant differences in conflict management style preferences due to the ethnic background, education and organization type while there are no significant differences due to gender. It is also found out that the most and least preferred styles are integrating and dominating, respectively, irrespective of demographics of the respondents. They differ in their second, third and fourth preferences. Similarly, results also show that ethnic background, education and organization type are the valid predictors of conflict management style preferences. The study contributes to the ongoing debate on changing conflict management style preferences and dynamic versus static models of culture. It also puts forth managerial recommendations with regards to recruitment and selection, $T \mathscr{E} D$, and posting and transfers. Directions for future research and limitations of the study are also discussed.
\end{abstract}

Keywords: Ethnic background, conflict management styles, organizational demography

\section{Introduction}

Conflict is omnipresent since the dawn of humanity. It ranges from interpersonal to inter-group and is thus infused in all forms of social relationships (Rahim, 2015). It is traditionally treated as destructive, although the debate is still on about its constructiveness and destructiveness (Riaz \& Junaid, 2014). But it is no more considered

1 Corresponding author, COMSATS Institute of Information Technology, Attock. Email: riaz@ciit-attock.edu.pk

2 Assistant Professor, Institute of Management Sciences, Peshawar. Email: waseef.jamal@imsciences. edu.pk

3 Professor, Department of Management Sciences, COMSATS Institute of Information Technology, Attock.Email:alijan@ciit-attock.edu.pk 
as totally disruptive, problematic and destructive. A group of researchers support its presence and its proper management for more efficient and effective organization (see for example, Tjosvold, 2008). All humans face conflict and consequently develop a specific way to manage it through different styles (Rahim, 2015). Different people have different preferences for these styles based on their personality (Ul-Haque, 2004), cultural values (Cai \& Fink, 2002), age (Mckenna \& Richardson, 1995; Cetin \& Hacifazlioglu, 2004), education (Pinto \& Ferrer, 2002), gender (Brahman, Margavio, Hignite, Barrier, \& Chin, 2005; Havenga, 2006), ethnic background (Kozan, 2002; Cai \& Fink, 2002), organization's type (Havenga, 2006) and other demographics (Voki \& Sontor, 2010). Similarly, Taras, Steel, and Kirkman (2016), Gunkel, Schlaegel, and Taras (2016), Abbasi and Ghziyani (2015), and Steel and Taras (2010) argued that aggregate national culture shall not be considered while studying organizational phenomena. Rather sub-culture (based on ethnic background, language, or geography) and other demographics too have substantial influence on organizational phenomena. This study, therefore, is aimed to investigate the conflict management style preferences; impact of ethnic background along with other demographics on these preferences; and knowing valid predictors of these preferences for working force belonging to six sub-cultures of Pakistan.

This study contributes to the ongoing debates i.e. the impact of ethnic background (sub-culture) and other demographics (age, gender, education etc.) on conflict management styles' preferences (Gunkel et al., 2016; Rosenthal \& Hautaluoma, 1988; McKenna \& Richardson, 1995; Sorenson, Hawkins, \& Sorenson, 1995; Brewer, Mitchell, \& Weber, 2002; Pinto \& Ferrer, 2002; Cetin \& Hacifazlioglu, 2004; Brahnam et al., 2005; Chan, Monroe, Ng, \& Tan, 2006; Havenga, 2006; Lee Agee \& Kabasakal, 1993; McKenna, 1995; McKenna \& Richardson, 1995; Elsayed-Ekhouly \& Buda, 1996; Morris et al., 1998; Kozan, 2002; Voki \& Sontor, 2010). Results of the study substantiates the stance taken by Vas Taras and his colleagues (see e.g., Taras et al., 2016; Taras, Steel, \& Kirkman, 2011; Steel \& Taras, 2010; Taras, Steel, $\&$ Kirkman, 2010) about the culture. According to them, (i) culture is not static as proposed by Hofstede (1980), rather it is dynamic and national culture is not the representative of the whole country's sub-cultures, and (ii) sub-culture is of immense importance and should be taken into consideration. The study also points to the fact that conflict management style preferences are changing with time. This point needs to be investigated in detail. Findings of the study will enable the managers to plan and implement selection and recruitment, training and development, transfer and postings in Pakistani context, specifically in Federally Administered Tribal Areas (FATA) and Khyber Pakhtunkhwa (KP).

In the next section, literature on conflict management styles and their historical 
developments along with organizational demography are discussed.

\section{Literature Review}

\subsection{Conflict Management Styles}

There are conflicts about the definition of conflict (Tjosvold, 2008). According to Pondy (1967) conflict emerges when one party perceives that its goals, values or views are being indulged by inter-reliant counterparts (Wall \& Callister, 1995; Thomas, 1992). While others (De Deru \& Gelfand, 2007; Deutch, 1973; \& Kelley \& Thibaut, 1969) opined that workplace conflict may arise because of scarce resources (for example time, status, budgets), values (such as political preferences, beliefs, religion, moral, social values), personality differences, misinterpreted facts, perceptions, world views and may be due to any combination” of these (Riaz \& Junaid, 2011).

Most of the people have specific and long lasting approach (style) towards conflict although it is possible that the context and other variables may affect their approach from time to time (Friedman, Tidd, Currall, \& Tsai, 2000). These styles are discussed thoroughly in conflict literature (Ul-Haque, 2004). Hocker and Wilmot (1991) define conflict management styles as "patterned responses or cluster of behaviors people use in conflict". The concept of conflict management styles has its roots in organizational studies (Ul-Haque, 2004); and in social psychology (Rahim, 2015).

Follet (1940), being the first researcher to discuss conflict management styles, suggested that there are three primary styles to handle the conflict i.e. domination, compromise and integration; and two secondary styles i.e. avoidance and suppression. Domination means the victory of one over the other conflicting party. In compromise each side gives up to accommodate others' concerns for reaching a solution but didn't like to give up while in integrating style, parties want to reach such a solution which is desirable to all of them. She described this style as the best one. Bales (1950) presented two dimensions, 'agreeableness' and 'activeness' to explain conflict behaviors. Bales defined agreement as "acceptance, understanding, concurrence, release of tension and solidarity" and disagreement as "withholding, showing, rejecting, tending and antagonizing" (Ul- Haque, 2004).

The first well defined conceptual framework was presented by Blake and Mouton (1964). Their managerial grid is based on two dimensions: 'concerns for production' and 'concerns for people'. The model is labeled as "Dual Concern Model” which was originally presented for the explanation of managerial behavior including managerial conflict behavior. Later on, Blake and Mouton (1970) argued that these two dimensions can explain the conflict behaviors of the all the conflicting parties irrespective 
of the position held by them. The interaction of these two dimensions gives rise to five conflict management styles: forcing, withdrawing, smoothing, compromising, and confrontation. Their Dual Concern Theory/Model hypothesizes that organizational conflict depends on the desires to obtain one's own goal in opposition to retain interpersonal relationships (Ul- Haque, 2004).

Thomas (1976) redesigned the bidimensional model by adopting new refined dimensions: 'assertiveness' and 'cooperativeness'. Assertiveness is defined as 'attempting to satisfy one's own concerns' and cooperativeness as 'attempting to satisfy other's concerns'. He argued that these two concerns are behavioral attributes rather than causal variables (Ul- Haque, 2004). He identified five styles i.e. competing, collaborating, avoiding, accommodating and compromising. Rahim and Bonoma (1979) adopted the same Dual Concern Theory but they gave different names to these dimensions i.e. "concern for self" and "concern for others". Concern for self dimensions determines the degree to which a party attempts to satisfy its own concerns. Similarly, the second dimension determines the degree to which a party wants to satisfy the concern of others. The interplay of these dimensions result in five styles, those are integrating, obliging, dominating, avoiding and compromising.

This study adopted Rahim's model of conflict management styles (Rahim, 2015) due to following reasons (i) it is based on Dual Concern Theory which is adopted in this study as anchoring theory, (ii) it is one of the most used model (Rahim, 2016), and (iii) the instrument based on this model Rahim's Organizational Conflict Inventory - version 2 (ROCI-II) have desired psychometric properties (Rahim \& Magner, 1995; Weider-Hatfield, 1988) and it is the most used conflict management styles instrument (Rahim, 2016)

In integrating style, concern for self and concern for others both are high (Rahim, 2015). Both sides' interests are considered and outcome is usually wise, durable, and efficient (Fisher \& Ury, 1991). If this approach is adopted, a solution will be of mutual acceptance (Pruitt, Carnevale, Ben-Yoav, Nochajski \& Van Slyk, 1983; Gray, 1989; Rahim, 2015; Pruitt \& Carnevvale, 1993). As this style involves intensive consideration, therefore, it is useful in complex conflicts where enough time and resources are available (Ul-Haque, 2004). Low concern for self and high concern for others is characterized by obliging style. In this style commonalities are considered and differences are ignored. It also has an element of self-sacrifice (Rahim, 2015). Some conditions like presence of pressure may encourage obliging style (Rubin, Pruitt, \& $\mathrm{Kim}, 2004$ ). And maybe it is adopted by the party which feels itself weaker (Cai \& Fink, 2002). Dominating style indicated high concern for self and low concern for others. Dominating party may go to any extent to get results of its interests (Rahim, 2015). In avoiding style, concerns for self and for others both are low. It's like "see no 
evil, hear no evil, speak no evil" (Rahim, 2015). This style may be adopted because pursuing benefit is not that much important (Cai \& Fank, 2002). And makes the persons/parties think that letting going the conflict will minimize the conflict (Pruitt $\&$ Rubin, 1986). Compromising style is characterized by moderate concern for self and others. It involves give and take and exchange of information for seeking a pareto optimal solution (Rahim, 2015). The context matters in the preference and adoption of the specific conflict management style (Pruitt \& Rubin, 1986).

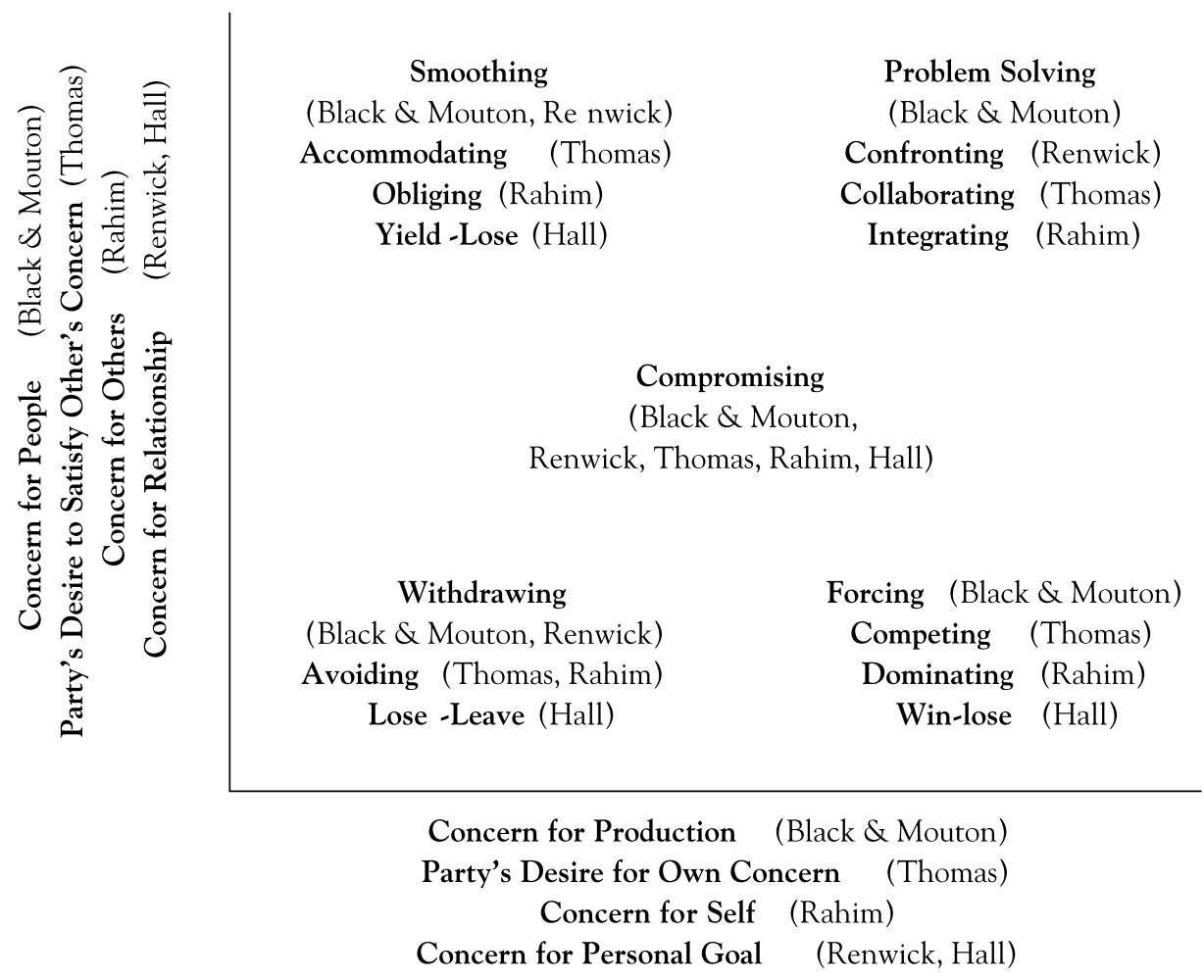

Figure 1: Summary of Conflict Management Styles Based on Dual Concern Model Adopted from Holt and DeVore (2005)

\subsection{Demographics and Conflict Management Styles}

In organizational studies demographics are hotly debated. Organizational demography is defined as the distribution of organizational members based on a specific de0mographic attributes, characteristics or trait (Mittman, 1992; Pfeffer, 1983). It is rooted in Structuralist Sociological Theories like Social Categorization Theory - SCT and Social Exchange Theory - SET. These theorists propound that members and propositions of social groups interact with each other as per their group demands (Blau, 1977; Simmel, 1955). These theories assume that positions among which 
social actors are distributed influence on their social life, values and cultural norms. It was hypothesized by Blau (1977) that differentiation along significant dimensions of social position creates social structure. These structures reflect and influence social actors' role inter-relations, social interactions, and associations. This is also conceptualized as a multi-dimensional space comprised of different positions. On these positions the population is distributed. These positions are characterized by demographic attributes like age, gender, experience, education, occupation, locality and many more (Blau, 1977).

Demographics influence conflict management style preferences (Vokić \& Sontor, 2010) such as age (Mckenna \& Richardson, 1995; Ceitin \& Hacifazlioglu, 2004), education (Pinto \& Ferrer, 2002), gender (Brahnam, Margavio, Hignite, Barrier, \& Chin, 2005; Havenga, 2006), ethnic background (Kozan, 2002; Cai \& Fink, 2002), and organization's type (Havenga, 2006). Therefore, aims of this research are to study (i) conflict management styles preferences, (ii) impact of ethnic background along with other demographics on these preferences, (iii) group differences regarding CMS preferences, and (iv) the valid predictors of these preferences in Pakistani working place. To achieve these objectives, research design is developed and discussed in the next section.

\section{Methodology}

\subsection{Research Questions}

To achieve the objectives of the study, following research questions are developed.

RQ1: What are the overall conflict management style preferences of respondents of six sub-cultures?

RQ2: What is the influence of demographics, specifically ethnic background and other demographics (age, gender, education, and organization type) on the conflict management style preferences of respondents?

RQ3: Did respondents differ significantly on conflict management style preferences due to ethnic background, age, gender, and organization type?

RQ4: What are the predictors of conflict management style preferences?

\subsection{Sampling and Demographics}

In this study, questionnaire is used as the data collection tool. For sampling, respondent driven sampling (RDS) is used which is a type of convenience sampling. 
The data is collected from a diverse population. This approach is adopted because matched sampling is not suitable for this study. Non-matched sampling minimizes the effect of organizational culture on the phenomenon under investigation (Taras et al., 2016). For this study, seeds (initial respondents) are chosen in government organizations, educational institutes, NGOs, and private/commercial organizations. The chosen seeds are given the questionnaires in hard as well the link (on google form) is sent to them. The selected seeds emailed the link to their peers. 300 questionnaires were collected. Four of these were excluded because those were not properly filled. 296 valid responses are analyzed. $81.8 \%$ were male $(n=242)$. The ethnic distribution of the respondents was as: 100 were Pakhtuns of Khyber Pakhtunkhwa, 65 were Pakhtuns of the FATA, 40 were Hindkowan, 40 were Chitralis, 34 were Punjabis, and 17 were Urdu speaking. Mean Age of the respondents was 30.67 years $(\mathrm{SD}=8.24$, range $=$ 18-68). There were $18 \mathrm{PhDs}$ (6.1\%), $80 \mathrm{MS} / \mathrm{MPhil}$ (27\%), while 185 was having 16 years of education (62.5\%) and 11 were having 14 years of education (3.7\%). Among the respondents $19.5 \%$ were from Govt. organizations, $21.3 \%$ were from Non-Govt. Organizations (NGOs), $29.1 \%$ from Educational institutions, $26.7 \%$ were from private (for profit) sector while $3.7 \%$ were from other types of organizations.

\subsection{Instruments}

Questionnaire of this study was comprised of two sections along with a covering page which describes the basic purpose of introducing the study. First section was about demographics. In second section there were questions about conflict management styles from Modified ROCI-II. This modified ROCI-II has 29 items with a Likert scale from 1 to 7 ( 1 for strongly disagree and 7 for strongly agree) measuring five distinct conflict management styles. The instrument has 7 items for measuring compromising style, 6 items for obliging style, 5 items for dominating style, 6 items for avoiding style and 5 items for integrating style. The Cronbach alphas values ranged from .71 to .85 which showed that constructs used were reliable. Cronbach alpha values for conflict management styles are: .80 (compromising), .84 (obliging), .71 (dominating), .81 (avoiding), and .84 (integrating).

\section{Analysis and Results}

Firstly, data is analyzed using descriptive statistics for investigating the overall conflict management preferences and demographics. Secondly, to find correlations, Spearman correlation matrix is utilized because of the nature of certain variables which are on ordinal scale. Third, ANOVA is used to investigate group differences; and lastly, regression analysis is carried out to know about the valid predictors of conflict management styles preferences. 
Table 1: Spearman Correlation

\begin{tabular}{|c|c|c|c|c|c|c|c|c|c|c|}
\hline & 1 & 2 & 3 & 4 & 5 & 6 & 7 & 8 & 9 & 10 \\
\hline $\begin{array}{c}\text { 1. Organiza- } \\
\text { tion Type }\end{array}$ & 1.00 & & & & & & & & & \\
\hline 2. Gender & .078 & 1.00 & & & & & & & & \\
\hline 3. Age & $-.196^{* *}$ & -.094 & 1.00 & & & & & & & \\
\hline $\begin{array}{c}4 . \text { Ethnic } \\
\text { Background }\end{array}$ & -.044 & $.116^{*}$ & $.206^{* *}$ & 1.00 & & & & & & \\
\hline $\begin{array}{c}\text { 5. Educa- } \\
\text { tion }\end{array}$ & $.150^{* *}$ & -.032 & $-.251^{* *}$ & .110 & 1.00 & & & & & \\
\hline $\begin{array}{c}\text { 6. Compro- } \\
\text { mising }\end{array}$ & $-.123^{*}$ & .013 & .014 & .005 & $-.103^{*}$ & 1.00 & & & & \\
\hline 7. Obliging & $-.157^{* *}$ & -.019 & -.003 & $-.065^{*}$ & .062 & $.446^{* *}$ & 1.00 & & & \\
\hline $\begin{array}{c}\text { 8. Dominat- } \\
\text { ing }\end{array}$ & -.014 & .009 & $-.115^{*}$ & -.001 & .027 & -.063 & .013 & 1.00 & & \\
\hline 9. Avoiding & -.058 & $.081^{*}$ & $-.107^{*}$ & $-.071^{*}$ & .009 & $.410^{* *}$ & $.465^{* *}$ & -.048 & 1.00 & \\
\hline $\begin{array}{c}\text { 10.Integrat- } \\
\text { ing }\end{array}$ & $-.173^{* *}$ & -.062 & .041 & $-.062^{*}$ & .075 & $.503^{* *}$ & $.441^{* *}$ & $-.122^{*}$ & $.255^{* *}$ & 1.00 \\
\hline
\end{tabular}

** Correlation is significant at the $\mathrm{p}<.01$ level (2-tailed). ${ }^{*}$ Correlation is significant at the $\mathrm{p}<.05$ level (2-tailed).

\subsection{Overall Respondents Preferences for Conflict Management Styles}

Table 2 shows the overall preferences or respondents for conflict management styles. As per the mean values of ANOVA test, respondents mostly prefer the integrating style of conflict management, followed by compromising style, followed by obliging style, avoiding style, followed by the least preferred style, i.e. dominating.

Table 2: Overall Preferences for Conflict Management Styles

\begin{tabular}{|c|c|c|c|}
\hline $\begin{array}{c}\text { Conflict Management } \\
\text { Style }\end{array}$ & Mean & SD & p-value \\
\hline Integrating & 5.75 & 1.10 & .000 \\
\hline Compromising & 4.96 & 1.00 & .000 \\
\hline Obliging & 4.84 & 1.06 & .000 \\
\hline Avoiding & 4.73 & 1.14 & .000 \\
\hline Dominating & 3.11 & 1.19 & .000 \\
\hline
\end{tabular}




\subsection{Demographics and Conflict Management Styles Preferences}

Table 3 shows the analysis of variance (ANOVA) results for different conflict management styles based on ethnic background, gender, education, and organization type.

Results show that ethnic groups differ significantly for compromising sand integrating styles, while they do not differ significantly for other styles, i.e. obliging, avoiding, and dominating. All groups' most preferred style is integrating while least preferred style is dominating. For Pakhtuns (FATA), Punjabis, and Hindko speaking groups, the second least preferred style is avoiding. Pakhtuns (KP) and Chitralis do not prefer obliging style mostly as this is their second least preferred style. Compromising is second most preferred style of Pakhtuns of (KP), Chitralis and Punjabis; while for Hindko speaking people (Hindkowan), and Pakhtuns of FATA, the second most preferred style is obliging.

Table 3: ANOVA Results

\begin{tabular}{|c|c|c|c|c|c|c|c|c|}
\hline \multirow{2}{*}{$\begin{array}{c}\text { Conflict } \\
\text { Style }\end{array}$} & \multicolumn{2}{|c|}{$\begin{array}{c}\text { Ethnic Back- } \\
\text { ground }\end{array}$} & \multicolumn{2}{|c|}{ Education } & \multicolumn{2}{c|}{ Organization Type } & \multicolumn{2}{c|}{ Gender } \\
\cline { 2 - 9 } & F-Value & Sig. & F-Value & Sig. & F-Value & Sig. & F-Value & Sig. \\
\hline Integrating & 3.275 & .05 & 2.52 & .05 & 2.221 & .05 & 1.211 & .35 \\
\hline $\begin{array}{c}\text { Compromis- } \\
\text { ing }\end{array}$ & 3.344 & .05 & 2.441 & .05 & 3.143 & .01 & 1.614 & .28 \\
\hline Obliging & 1.071 & .38 & 1.121 & .32 & 2.076 & .05 & 1.012 & .41 \\
\hline Avoiding & .767 & .59 & 1.011 & .61 & 2.284 & .05 & .989 & .72 \\
\hline Dominating & .369 & .89 & .549 & .67 & .896 & .48 & .721 & .67 \\
\hline
\end{tabular}

No significant difference is found regarding the preferences for conflict management styles based on gender as evident from the values in Table 3. Also, the mean difference results (not reported here) showed that both genders preferred integrating style mostly, followed by compromising style. For the third and fourth preferred styles, however, both genders differed, i.e. males preferred obliging style, followed by avoiding style; whereas females preferred avoiding style, followed by obliging style. For both genders, the least preferred style found was dominating.

Based on education, ANOVA results show that respondents differ significantly in preferences for compromising style and integrating style only. There are no significant differences found for other conflict management styles. Also, the mean difference results show that avoiding style is the second least preferred style of those who have 18 years of education and 16 years of education. Integrating style is the most preferred 
style of conflict management of all the respondents. Obliging is the second most preferred style of respondents whose education is of 14 years; whereas for respondents with $\mathrm{PhD}$ degree, it is the second least preferred style. Compromising is the second most preferred style of $\mathrm{PhDs}$, and respondents with 18 and 16 years of education.

On the basis of organization type, ANOVA results show that respondents differ significantly over compromising, obliging, avoiding, and integrating styles.

\subsection{Predictors of Conflict Management Styles}

Table 4 reports regression results. Result reveal that for avoiding style, organization type and gender are valid predictors. For integrating style, organization type and ethnic background are the valid predictors. Organization type and education are the valid predictor of obliging style. Similarly, for compromising style of conflict management, organization type is the valid predictors. There is no valid predictor found for the dominating style.

Table 4: Regression Analysis

\begin{tabular}{|c|c|c|c|c|c|}
\hline & Compromising & Obliging & Dominating & Avoiding & Integrating \\
\hline Gender & .013 & -.058 & .11 & $.263^{*}$ &. .134 \\
\hline Age & .003 & .002 & -.016 & -.013 & .010 \\
\hline $\begin{array}{c}\text { Ethnic Back- } \\
\text { ground }\end{array}$ & -.006 & -.025 & -.006 & -.030 & $-.044^{*}$ \\
\hline Education & -.090 & $.146^{*}$ & .010 & -.015 & .209 \\
\hline $\begin{array}{c}\text { Organization } \\
\text { Type }\end{array}$ & $-.128^{*}$ & $-.149^{*}$ & -.047 & $-.111^{*}$ &. $.147^{*}$ \\
\hline F Values & $1.839^{*}$ & $2.012^{*}$ & .774 & $1.672^{*}$ & $2.389^{* *}$ \\
\hline R2 Values & .034 & .034 & .013 & .028 & .40 \\
\hline
\end{tabular}

** Correlation is significant at the $\mathrm{p}<.01$ level (2-tailed). ${ }^{*}$ Correlation is significant at the $\mathrm{p}<.05$ level (2-tailed).

\section{Conclusion}

This study investigated conflict management styles preferences of Pakhtuns (FATA), Pakhtuns (KP), Chitralis, Hindkowan, Punjabis and Urdu Speaking community working in Govt./Public sector, Non-Govt. Organizations (NGOs), educational, and commercial organizations. The correlation analysis, ANOVA and regression analysis revealed interesting findings along with the impact of demographics on these preferences. 
There are very few studies conducted in Pakistan for determining the conflict management styles. Ul-Haque (2004) aimed to find impact of personality dimensions on the conflict management styles of corporate sector managers of Pakistan and found that the most preferred style is integrating, then avoiding, obliging and dominating. The least preferred style was compromising. There are also mixed results of two recent studies. In Chuadhry, Sajjad and Khan (2011) study respondents were from a public sector organization of Pakistan, investigated the impact of age on conflict style preferences. They concluded that avoiding was the most preferred style, followed by obliging, integrating, compromising while the least preferred style was dominating. The study of Ud-Din, Khan, Rehman and Bibi (2011) conducted in higher education sector of Khyber-Pakhtunkhwa, found out that the most preferred style is integrating then compromising, avoiding and obliging. The least preferred style was dominating. Chaudhry et al. (2011) contradicted the findings of this study and of Ul-Haque (2004) and Ud-Din et al. (2011). That may be because of the narrow sample of respondents of their study, which were from a public sector organization.

This study has taken ethnic background, age, gender, education, and organization type into consideration for the conflict management styles preferences, revealed some interesting results. The overall preferences of the respondents for conflict styles are as: most preferred style is integrating, followed by compromising, obliging and avoiding while least preferred style is dominating style which corroborated the findings of Ul-Haque (2004) but differ with other studies mentioned. This study supports the dynamic culture school of thought (Steel \& Taras, 2010; Taras et al., 2011) as results of this study rejected the presumptions of static categorization of countries / national cultures based on Hofstede $(1980,1991)$ static cultural values theory and its preferences for conflict management styles because this study shows that ethnic background (sub-culture) play an important role in shaping the preferences for conflict management styles. Accordingly, this study supported those previous studies which rejected the static categorization of cultures at aggregate national level as individualist or collectivists, and therefore were supposed to prefer some styles more than other (see for example, Ting-Toomy et al., 1991; Cai \& Fink, 2002; Ma, Erkus \& Tabak, 2010; Croucher, 2011; Croucher, Holody, Hicks, Oommen, \& DeMaris, 2011; Khakimova, 2008; Hung, 2005; Steel \& Taras, 2010; Taras et al., 2011).

The study provided empirical support and evidences that ethnic background along with other demographics has a substantial influence on conflict management style preferences.

\section{a. Managerial Implications}

This study suggested that identification of preferences for conflict management 
style with relation to demographics is of immense importance. Hence, the following recommendations are proposed to the managers of organizations working in Pakistan.

At the time of selection and recruitment, along with the aptitude tests, and personality tests; conflict management styles preferences may also be investigated, so that personality - job fit goal is achieved. This ethnic background (sub-culture) and conflict management style preferences profiles of new employees will facilitate their supervisor/ manager to deal them pragmatically. This in turn will strengthen the organization citizenship behaviors (OCBs) and minimize counterproductive work behaviors (CWBs). It will also help in the training need assessment (TNA) to assess the training needs regarding personal development and conflict management skills development. Subsequently, it will increase return on investment (ROI) of trainings in termsof enhanced productivity and efficiency. Transfers and posting in the FATA (Federal Administered Tribal Areas - Tribal areas of Pakistan) region will also be productive for the organization if these phenomena are taken into consideration. According to the positive conflict school of thought if workplace conflict is managed properly it can help the organization to achieve its strategic goals with increased productivity, enhanced efficiency, lesser turn-over, healthy working environment, satisfied staff, strengthened OCBs and minimized CWBs (Deutch, 1973; Tjosvold 2008).

\section{b. Limitations and Future Directions}

The study being first of its nature in Pakistan; contributed to the body of knowledge and also suggested several recommendations, still should be viewed with caution due to its several limitations. The first limitation is the tool used i.e. questionnaire which is a self-report tool which may result in social desirability bias. This use of self-report tool may lead to several shortcomings as this tool measure the respondents' attitudes not the actual behaviors. This in turn means that it is not certain that these attitudes are translated to actual behaviors or not? This limitation may be addressed by utilizing mixed methods. Another limitation is the non-generalizibility of this study which may arise due to the following reasons. (i) The use of respondent driven sampling (type of snow-ball sampling), (ii) low response rate may result in non-response bias. To overcome these limitations, it is advised that the future researchers may recruit large number of respondents, representative of their sub-cultures. Longitudinal studies will help in increasing the generalizability and determining causal relationships.

Overall this study may be considered the first step in knowing that how ethnic background (sub-culture) and other demographics affects the conflict styles preferences. Further studies will help in understanding the human resources belonging to sub-cultures of the Pakistan as suggested by Riaz and Jamal (2012). That will enable us to plan and deal with these human resources properly to benefit the economy of 
the country.

\section{References}

Abbasi, B., \& Ghaziyani, F. N. (2015). The relation between individual-social factors and conflict management styles: an empirical case study. International Journal of Productivity and Quality Management, 16(2), 231-247.

Bales, R. F. (1950). Interaction process analysis: A method for the study of small groups. Oxford, England: Addison-Wesley.

Blau, P. M. (1977). Inequality and heterogeneity. New York: Free Press

Blake, R. R., \& Mouton, J. S. (1964). Managing inter-group conflict in industry. Houston: Gulf.

Blake, R. R., \& Mouton, J. S. (1970). The fifth achievement. Journal of Applied Behavioral Science, 6(4), 413-426.

Brahnam, S. D., Margavio, T. M., Hignite, M. A., Barrier, T. B., \& Chin, J. M. (2005). A bender-based categorization for conflict resolution. Journal of Management Development, 24(3), 197-208.

Brewer, N., Mitchell, P., Weber, N. (2002). Gender role, organizational status, and conflict management styles. International Journal of Conflict Management, 13(1), 78-94.

Cai, D., \& Fink, E. (2002). Conflict style differences between individualists and collectivists. Communication Monograph, 69(1), 67-87.

Cetin, M. O., \& Hacifazlioglu, O. (2004). Conflict management styles: A comparative study of university academics and high school teachers. Journal of American Academy of Business, 5(1/2), 325-332.

Chan, C. C. A., Monroe, G., Ng, J., \& Tan, R. (2006). Conflict management styles of male and female junior accountants. International Journal of Management, 23(2), 289-295.

Chaudhry, A. A., Sajjad, M., \& Khan, I. (2011). Employees' conflict management strategies and

demography: A case of Pakistan. African Journal of Business Management, 5(9), 3549-3555.

Croucher, S. (2011). Muslim and Christian conflict styles in Western Europe. International Journal of Conflict Management. 22(1), 60-74

Croucher, S. M., Holody, K. J., Hicks, M. V., Oommen, D., \& DeMaris, M. (2011). An examination of conflict style preferences in India. International Journal of Conflict Management, 22(1), 10-34.

Deutsch, M. (1973). The resolution of conflict. New Haven, CT: Yale University Press.

Elsayed-Ekhouly, S. M., \& Buda, R. (1996), Organizational conflict: A comparative analysis of conflict styles across cultures. International Journal of Conflict Management, 7(1), 71-81.

Fisher, R., \& Ury, W. (1981). Getting to yes: Negotiating agreement without giving in. New York: Penguin Books. 
Follett, M. P. (1940). Constructive conflict. In H. C. Metcalf \& L. Urwick (Eds.), Dynamic administration: The collected papers of Mary Parker Follett. (pp. 30-49). New York: Harper and Row.

Friedman R. A., Tidd S. T., Currall S. C., \& Tsai, J. C. (2000). What goes around comes around: The impact of personal conflict styles on work conflict and stress. International Journal of Conflict Management, 11(1), 32-35.

Gray, B. (1989). Collaborating: Finding common ground for multiparty problem. San Diego.

Gunkel, M., Schlaegel, C., \& Taras, V. (2016). Cultural values, emotional intelligence, and conflict handling styles: A global study. Journal of World Business, 51, 568-585.

Hall, J. (1969). Conflict measurement survey: A Survey of one's characteristic reaction to and handling conflict between himself and others. Canoe, TX: Teleometrics International

Havenga, W. (2006), Relationships between gender/age - status differences and conflict management styles in small business. Retrieved on August 24, 2011 from http://www.kmu.unisg.ch/rencontres/ RENC2006/Topics06/D/Rencontres_2006_HavengaW.pdf

Hocker, J. L., \& Wilmat, W. W. (1991). Interpersonal conflict. Boston: McGraw Hills.

Hofstede, G. (1980). Culture's consequences: International differences in work related values. Newbury Park: Sage Publications.

Hofstede, G. (1991). Culture and organizations: Software of the mind. London, England: McGraw-Hill.

Holt, J. F., \& DeVore, C. J. (2005). Culture, gender, organizational role, and styles of conflict resolution: A meta-analysis. International Journal of Intercultural Relations 29, 165-196.

Kelley, H. H., \& Thibaut, J. W. (1969). Group problem solving. In G. Lindzey \& E. Aronson (Eds.), The handbook of social psychology. (pp. 1-101). Reading, Mass.: Addison-Wesley.

Khakimova, L. (2008). Conflict management styles among young Arabs and Americans: Exploring the effects of ethnic identity and self-construal. Unpublished Master Dissertation, University of Kansas, US.

Kozan, M. K. (2002). Sub cultures and conflict management style. Management International Review, 42(1), 89-105.

Lee Agee, M., \& Kabasakal, H. E. (1993). Exploring conflict resolution styles: A study of Turkish and American university business students. International Journal of Social Economics, 20(9), 3-14.

Ma, Z., Erkus, A., \& Tabak, A. (2010). Explore the impact of collectivism on conflict management styles: A Turkish study. International Journal of Conflict Management. 21(2), 169-185.

McKenna, S. (1995). The business impact of management attitudes towards dealing with conflict: A cross-cultural assessment. Journal of Managerial Psychology, 10(7), 22-27. 
McKenna, S., \& Richardson, J. (1995). Business values, management and conflict handling: Issues in contemporary Singapore. Journal of Management Development, 14(4), 56-70.

Mittman, B. S. (1992). Theoretical and methodological issues in the study of organization demography and demographic change. In Tolbert, P. S. \& Bacharach, S. B. (Eds.), Research in the Sociology of Organization. (pp. 3-53). Greenwich: JAI Press

Morris, M. W., Williams, K. Y., Leung, K., Larrick, R., Mendoza, M. T., Bhatnagar, D., Li, J., Kondo, M., Luo, J. L., Hu, J. C. (1998). Conflict management style: Accounting for cross-national differences. Journal of International Business Studies. 29(4), 729-747.

Pfeffer, J. (1983). Organizational demography. In Cummings, L. L. \& Staw, B. M. (Eds), Research in Organizational Behavior. (pp. 299-357). Greenwich: JAI Press.

Pinto, E. P., \& Ferrer, J. Jr. (2002). Relationship between demographic characteristics and conflict handling styles. The Center for Latin American Issues Working Paper Series. Retrieved on August 24, 2011 from www.gwu.edu/ clai/working_papers/Paschoal_Eder_05-02.pdf

Pondy, L. (1967). Organizational conflict: Concepts and models. Administrative Science Quarterly, 12(2), 296-320.

Pruitt, D. G., \& Carnevale, P. J. (1993). Negotiation and social conflict. Buckingham: Open University Press.

Pruitt, D. G., \& Rubin, J. Z. (1986). Social conflict: Escalation, stalemate, and settlement. New York: Random House.

Pruitt, D. G., Carnevale, P. J., Ben-Yaoav, O., Nochajski, T. H., \& Van Slyk, M. (1983). Incentive for cooperation in integrative bargaining. In R. Tietz (Ed), Aspiration levels in bargaining and economic decisions making. (pp. 22-34). Berlin: Springer

Rahim, M. A. (2016). ROCI-II Bibliography. Retrieved on August 25, 2016 from http://people.wku.edu/ afzal.rahim/ROCI-Bibl.doc

Rahim, M. A. (1983). A measure of styles of handling interpersonal conflict. Academy of Management Journal, 26(2), 368-376.

Rahim, M. A. (2015). Managing conflict in organizations ( $5^{\text {th }}$ ed.). London: Quorum Books

Rahim, M. A., \& Bonoma, T. V. (1979). Managing organizational conflict: A model for diagnosis and intervention. Psychological Reports, 44(3), 1323-1344.

Rahim, M. A., \& Magner, N. R. (1995). Confirmatory factor analysis of the styles of handling interpersonal conflict: First-order factor model and its invariance across groups. Journal of Applied Psychology, $80(1), 122-132$.

Riaz, M. K., \& Junaid, F. A. (2011). Types, sources, costs \& consequences of workplace conflict. Asian Journal of Management Research, 2(1), 600-611. 
Riaz, M. K, \& Junaid, F. A. (2014). Workplace conflict: Constructive or destructive. SRM -IMT Journal of Business $\mathcal{E}$ Management Research, 3(1), 84-90.

Riaz, M. K., \& Jamal, W. (2012). Horizontal \& vertical individualism - collectivism and conflict management styles: A Pakistani sub-cultural model. 25th Annual International Association of Conflict Management Conference, Cape Town, South Africa. Retrieved on December 24, 2012 from http:// papers.ssrn.com/sol3/papers.cfm?abstract_id=2040582

Rosenthal, D. B., \& Hautaluoma, J. (1988). Effects of importance of issues, gender, and power of contenders on conflict management style. Journal of Social Psychology, 128(5), 699-701.

Rubin, J. Z., Pruitt, D. G., \& Kim, S. H. (2004). Social conflict: escalation, stalemate, and settlement. New York: McGraw-Hill

Simmel, G. (1955). Conflict and the web of group-affiliations. New York: Free Press

Sorenson, P. S., Hawkins, K., \& Sorenson, R. L. (1995). Gender, psychological type and conflict style preference. Management Communication Quarterly, 9(1), 115-126.

Steel, P., \& Taras, V. (2010). Culture as a consequence: A multi-level multivariate meta-analysis of the effects of individual and country characteristics on work-related cultural values. Journal of International Management, 16(3), 211-233.

Taras, V., Kirkman, B. L., \& Steel, P. (2010). Examining the impact of culture's consequences: a three-decade, multi-level, meta-analytic review of Hofstede's cultural value dimensions. Journal of Applied Psychology, 95(3), 405-439.

Taras, V., Steel, P., \& Kirkman, B. L. (2011). Three decades of research on national culture in the workplace: Do the differences still make a difference? Organizational Dynamics, 40(3), 189-198.

Taras, V., Steel, P., \& Kirkman, B. L. (2016). Does country equate with culture? Beyond geography in the search for cultural boundaries. Management International Review, 56(4), 455-487.

Thomas, K. W. (1976). Conflict and conflict management. In M. D. Dunnette (Ed.), Handbook of Industrial and Organizational Psychology. (pp. 889-935). Chicago: Rand-McNally.

Thomas, W. K. (1992). Conflict \& conflict management: Reflections and updates. Journal of Organizational Behavior, 13(3), 265-274.

Ting-Toomey, S., Gao, G., Trubisky, P., Yang, Z., Kim, H. S., Lin, S. L., \& Nishida, T. (1991). Culture, face maintenance, and styles of handling interpersonal conflict: A study of five cultures. International Journal of Conflict Management, 2(4),275-29

Tjosvold, D. (2008). The conflict-positive organization: It depends upon us. Journal of Organizational Behavior, 29(1), 19-28.

Ud-Din, S., Khan, B., Rehman, R., \& Bibi, Z. (2011). An investigation of conflict management in public and private sector universities. African Journal of Business Management, 5(16), 6981-6990. 
Ul-Haque, M. A. (2004). Personal attributes and conflict management styles of corporate managers. Unpublished doctoral dissertation, University of Peshawar, Peshawar. Retrieved on April 4, 2012 from http:// eprints.hec.gov.pk/6858/1/3653H.htm

Vokić, N. P., \& Sontor, S. (2010). The relationship between individual characteristics and conflict handling styles - the case of Croatia. Problems and Perspectives in Management, 8(3), 56-67.

Wall, J., \& Callister, R. (1995). Conflict and its management. Journal of Management, 21(3), 515-558.

Weider-Hatfield, D. (1988). Assessing the Rahim organizational conflict inventory-II (ROCI-II). Management Communication Quarterly, 1(3), 350-366. 
